\title{
Faktor - faktor yang Mempengaruhi Penerapan Corporate Social Responsibility (CSR) di Perusahaan
}

\author{
Herawati Ningrum ${ }^{1}$, Alma Avida Purnama ${ }^{2}$, Alysa Oktaviana ${ }^{3}$, Giovani Calista ${ }^{4}$, Ida Farida Adi Perwira ${ }^{5}$, \\ Arim Nasim ${ }^{6}$ \\ Akuntansi, Fakultas Pendidikan Ekonomi dan Bisnis, Universitas Pendidikan Indonesia, Bandung, Indonesia \\ herawatiningrum@student.upi.edu' ${ }^{1}$, alma.avidapurnama@student.upi.edu ${ }^{2}$, alysaoktaviana@ student.upi.edu ${ }^{3}$, \\ giovanicalista@student.upi.edu ${ }^{4}$, ida.farida@upi.edu ${ }^{5}$, arim.nasim@upi.edu ${ }^{6}$
}

\begin{abstract}
This study discusses CSR (Corporate Social Responsibility) which is a form of social responsibility carried out by the company to the community around the company environment. Companies implementing CSR activities can be used as a means to increase profits and enhance the company's reputation. This study aims to determine what factors influence the application of CSR in the company. The object of research is the factors that influence the application of CSR. This type of research is descriptive analysis. This study uses literature review by reviewing several journals that have been published by researchers and previous academics. The research design used is a quantitative descriptive method that is the analysis of data sources based on theories and concepts the companies that implement CSR into writing that leads to the discussion of this article. The method of data collection is the study of documents sourced from online journal provider sites. The results analyze that CSR factors implemented in the company such as company age, type of industry, company size, employee demand, government policy, organizational culture, and customer demand. These factors affect according to the situation and conditions in the environment. The limitation of this research article is that the writer only uses a few journals studied so that it is less relevant and there are differences from CSR factors applied by each company. The implication of this research is to show the characteristics of companies that play an important role in the practice of implementing CSR.
\end{abstract}

Abstrak: Penelitian ini membahas mengenai CSR (Corporate Social Responsibility) yang merupakan bentuk tanggung jawab sosial yang dilakukan oleh perusahaan kepada masyarakat di sekitar lingkungan perusahaan. Perusahaan mengimplementasikan kegiatan CSR ini dapat digunakan sebagai sarana untuk meningkatkan keuntungan dan meningkatkan reputasi perusahaan. Penelitian ini bertujuan untuk mengetahui faktor-faktor apa saja yang dapat mempengaruhi penerapan CSR di perusahaan. Objek Penelitian yang diteliti yaitu Faktor - faktor yang mempengaruhi penerapan CSR. Jenis penelitian ini adalah analisis deskriptif. Penelitian ini menggunakan literature review dengan cara mengkaji kembali beberapa jurnal yang telah dipublikasikan oleh para peneliti dan akademisi sebelumnya. Desain penelitian yang digunakan adalah metode deskriptif kuantitatif yaitu analisis sumber data berdasarkan teori dan konsep untuk dijabarkan menjadi tulisan tulisan yang mengarah ke pembahasan artikel ini. Metode pengumpulan data adalah dengan studi dokumen yang bersumber dari situs penyedia jurnal online. Hasil penelitian menunjukkan bahwa faktor CSR yang diimplementasikan di perusahaan misalnya usia perusahaan, jenis industri, ukuran perusahaan, permintaan karyawan, kebijakan pemerintah, budaya organisasi, dan permintaan pelanggan. Faktor tersebut berpengaruh sesuai dengan situasi dan kondisi di lingkungannya. Keterbatasan artikel penelitian ini adalah penulis hanya menggunakan beberapa jurnal yang diteliti sehingga kurang relevan serta terdapat perbedaan dari faktor-faktor CSR yang diterapkan oleh setiap perusahaan. Impilkasi penelitian ini adalah untuk menunjukkan karakteristik perusahaan yang memainkan peran penting dalam praktik penerapan CSR perusahaan.

Kata Kunci: CSR (Corporate Social Responsibility); companies; CSRD 


\section{PENDAHULUAN}

Corporate Social Responsibility (CSR) dikenal dengan istilah lain seperti tanggung jawab perusahaan, akuntabilitas perusahaan, pengelolaan, etika perusahaan, tanggung jawab masyarakat, dsb. CSR merupakan praktik atau kegiatan organisasi yang bertujuan untuk mempertahankan kondisi perusahaan di lingkungan kompetitif global. CSR memberikan kembali sebagian keuntungan yang diperoleh perusahaan melalui berbagai kegiatan kepada pemangku kepentingan (masyarakat, pemegang saham, karyawan, dan lingkungan). Berdasarkan penelitian jurnal sebelumnya yang dilakukan Renata Kučerová dalam jurnal yang berjudul "Factors Influencing The Implementation Of The CSR Concept In The Czech Republic" mengungkapkan bahwa ukuran perusahaan dan bentuk kepemilikan perusahaan memiliki pengaruh yang signifikan terhadap kontribusi perusahaan dalam kegiatan CSR. Ia mengungkapkan bahwa bila ukuran organisasi tersebut semakin besar, maka potensi organisasi tersebut melakukan kegiatan CSR akan sangat besar pula, kemudian factor struktur kepemilikan asing dan memiliki cabang di luar negeri juga mempengaruhi adanya kegiatan CSR di perusahaan tersebut. Sedangkan, menurut Gloria AnyangoOoko dalam jurnal yang berjudul "The Environmental Factors That Influence Implementation Of Corporate Social Responsibility (CSR) In an Organization" menjelaskan bahwa etika perusahaan merupakan faktor utama yang memotivasi perusahaan untuk terlibat dalam kegiatan CSR. Karena, dengan adanya etika dalam perusahaan tersebut, rasa kewajiban untuk melakukan kegiatan CSR akan timbul supaya dapat memberikan sesuatu yang bermanfaat kepada masyarakat atas berdirinya organisasi tersebut. Dari jurnal diatas dapat dilihat adanya faktor yang berbeda dalam penerapan kegiatan CSR di perusahaan. Jurnal ini akan membahas mengenai apa saja faktor $C S R$ yang ada di perusahaan dan bagaimana pengaruh faktor faktor tersebut dalam penerapan $C S R$ di perusahaan. Tujuan dari penulisan jurnal ini adalah untuk mengetahui apa saja faktor - faktor CSR di perusahaan dan seberapa besar pengaruh dari faktor faktor tersebut dalam penerapan CSR di perusahaan.

\section{METODEPENELITIAN}

Jenis penelitian ini adalah literature review atau studi kepustakaan yang artinya adalah mengkaji kembali atau meninjau berbagai literature yang telah dipublikasikan oleh para peneliti lain dan akademisi sebelumnya, terkait dengan topik bahasan yang akan diteliti. Sedangkan sifat dari penelitian ini adalah analisis deskriptif dengan memusatkan perhatian pada masalah, kemudian diolah dan dianalisis untuk diambil kesimpulannya. Studi kepustakaan menggunakan data sekunder yang bersumber dari literatur dan jurnal terdahulu yang relevan dengan topik pembahasan. Metode pengumpulan data adalah dengan studi dokumen yang bersumber dari situs penyedia jurnal online berbasis internasional seperti: emeraldinsight, google schoolar, researchgate, sciencedirect, tailorandfrancis dan eajournals. Setelah melalui proses seleksi dari sekian banyaknya jurnal yang ditemukan, sebanyak total 30 artikel telah dipilih sebagai bahan penelitian ini.

\section{HASIL DAN PEMBAHASAN}

Berdasarkan jurnal yang telah dianalisis, penelitian menunjukkan bahwa terdapat faktor-faktor yang dapat mempengaruhi implementasi CSR di perusahaan. Usia perusahaan, jenis industri, dan ukuran perusahaan, merupakan faktor yang berhubungan positif dengan penerapan CSR. Temuan kuantitatif dalam penelitian tersebut membuktikan bahwa perusahaan yang lebih tua (usia perusahaan) memiliki tingkat CSRD yang lebih tinggi dibandingkan dengan perusahaan yang masih baru. Selain itu, perusahaan dengan jenis manufaktur memiliki tingkat CSRD yang lebih tinggi karena dianggap lebih sensitif terhadap lingkungan. Sedangkan menurut temuan kualitatif, ketiga faktor tersebut yaitu ukuran perusahaan, usia perusahaan, dan jenis industri dapat menjelaskan perbedaan tingkat CSRD di perusahaan. ${ }^{[13]}$ Jenis perusahaan juga dibahas menjadi salah satu faktor yang berhubungan positif dengan CSR, dalam jurnal yang berbeda, temuan kuantitatif dalam jurnal tersebut mengungkapkan bahwa perusahaan jenis industri (manufaktur) lebih memiliki dampak / risiko yang lebih besar terhadap lingkungan sekitar sehingga memiliki skor tanggung jawab sosial perusahaan (CSR) yang lebih tinggi daripada perusahaan dari sektor lain. Ditemukan bahwa perusahaan yang paling mencemari dengan risiko lingkungan tertinggi (kehutanan dan kertas, 
pertambangan, minyak dan produsen gas, gas, air, dan multi-utilitas, sektor tembakau dan listrik.) akan mempengaruhi perusahaan tersebut dalam menerapkan CSR pada organisasinya. ${ }^{[14]} \mathrm{CSR}$ memberikan dorongan yang sangat penting untuk pengembangan perusahaan dalam bidang apapun. ${ }^{[15]}$ Maka dari itu CSR merupakan sumber daya yang berharga, yang sejalan dengan pandangan basis sumber daya perusahaan yang misalnya pemangku kepentingan dan argumen nilai bersama. ${ }^{[16]}$ Dalam jurnal lain pengujian statistik juga membuktikan bahwa ukuran perusahaan dapat mempengaruhi implementasi CSR diperusahaan, namun ada faktor lain yang muncul, yaitu bentuk kepemilikan asing yang berpengaruh besar terhadap penerapan CSR. Jurnal ini menyebutkan pengaruh dari struktur kepemilikan perusahaan tersebut, jika kepemilikan perusahaan itu sebagian besar dikuasai oleh asing, maka kegiatan CSR di perusahaan tersebut akan semakin banyak diterapkan, juga perusahaan yang memiliki cabang di luar negeri ikut berpengaruh dalam seberapa besar kegiatan CSR dilakukan. ${ }^{[17]}$ Selaindarifaktor - faktor diatas, jurnal lain berpendapat bahwa permintaan karyawan, kebijakan pemerintah, budaya organisasi, serta permintaan pelanggan adalah faktor utama lain yang dapat mempengaruhi CSR. Ini menunjukan bahwa keterlibatan CSR dapat menciptakan itikad baik bagi organisasi perusahaan dan seiring waktu akan mempengaruhi peningkatan kepedulian terhadap adanya tanggung jawab sosial perusahaan terhadap karyawan, meningkatkan produktivitas perusahaan dan dapat mengurangi pergantian tenaga kerja. Faktor budaya perusahaan dianggap dapat mempengaruhi kemampuan perusahaan dalam menunjukkan CSR karena adanya nilai-nilai bersama, kepercayaan, dan cara bekerja akan 'memengaruhi perilaku karyawan di tempat kerja, dan nilai-nilai yang tertanam dalam perusahaan juga memengaruhi para pembuat keputusan di perusahaan sehingga dianggap budaya organisasi yang baik akan ikut meningkatkan implementasi CSR di perusahaan. ${ }^{[18]}$ Faktor budaya lain yang mempengaruhi penerapan CSR juga disinggung dalam salah satu jurnal yang menyebutkan bahwa memanfaatkan konteks budaya lokal dapat mendukung dan meningkatkan implementasi CSR di tingkat pabrik (perusahaan). Kemudian, tingkat perkembangan sosial ekonomi juga mempengaruhi implementasi CSR, karena dengan meningkatnya kompetensi manajerial akan ikut meningkatkan tingkat pendidikan yang lebih tinggi. ${ }^{[19]}$ Selain itu ada juga Faktor yang disebut perencanaanstrategis formal yang ikut berpengaruhdalamimplementasi CSR di perusahaan. Dalam jurnal disebutkan bahwa perencanaan strategis formal memiliki kaitan dengan CSR karena perusahaan yang secara sistematis menganalisis kondisi lingkungan, mengalokasikan sumber daya untuk perencanaan dan memastikan integrasi fungsional untuk mengatasi masalah pasar dan non-pasar, akan menghasilkan CSR yang jelas. Berdasarkan pendapat diatas dapat disimpulkan bahwa perusahaan yang mengadopsi pendekatan formal untuk perencanaan strategis akan mengembangkan wawasan yang mendalam tentang tuntutan tanggung jawab sosial, sehingga memungkinkan dan mempromosikan kebijakan dan praktik CSR di perusahaannya. ${ }^{[20]}$

Penelitian mengenai penerapan CSR di berbagai negara memiliki banyak faktor yang berbeda. Faktor seperti Internal dan Eksternal pernah diteliti oleh salah satu jurnal yang membahas mengenai pengaruh penerapan CSR dalam kegiatan perbankan di kota Ho Chi Minh. Dalam jurnal tersebut dijelaskan bahwa Faktor Internal dan Eksternal ikut berpengaruh penting dalam penerapan CSR. Faktor Internal yang diteliti ikut berpengaruh positif yaitu kualitas sumber daya manusia, kualitas pelayanan, aktivitas pemasaran, kemampuan keuangan, dan kemampuan teknologi perusahaan. Sedangkan untuk Faktor Eksternalnya yang berpengaruh positif dengan penerapan CSR yaitu Pertumbuhan ekonomi, tingkat inflasi tahunan, lingkungan sosial dan politik serta konsumen. ${ }^{[21]}$ Kami juga menemukan bahwa faktor profitabilitas perusahaan adalah pendorong utama bagi perusahaan yang terdaftar di Mesir untuk mengungkapkan informasi penerapan CSR. Kami juga menemukan hubungan negatif antara komunitas dan tipe audit. Kemudian, sesuai dengan penelitian sebelumnya kami menemukan bahwa variabel lain yang diteliti yaitu struktur kepemilikan, ukuran perusahaan, gearing, likuiditas tidak mendorong keputusan pelaporan CSR di Mesir. ${ }^{[22]}$ Penelitian di Malaysia juga menyebutkan bahwa dari ketiga variabel yang diteliti, hasil akhirnya menunjukkan bahwa semakin tinggi ekspektasi ketiga aspek tersebut, yaitu Legal CSR, CSR Etis-filantropis dan CSR 
Ekonomi berhubungan positif dengan adanya dorongan kegiatan tanggung jawab sosial (CSR) perusahaan di Malaysia. Hal ini terjadi karena konsumen di Malaysia cenderung mengharapkan perusahaan untuk mematuhi norma-norma sosial dan hukum daripada hanya mencapai tingkat kinerja ekonomi yang tinggi, sedangkan harapan etis-diskresioner tercermin dalam kesiapan pelanggan untuk mendukung perusahaan yang bertanggung jawab atau menghukum yang tidak bertanggung jawab. Berdasarkan studi sebelumnya dari temuan empiris menunjukkan bahwa tanggung jawab etis-filantropis tampaknya mengarah pada keunggulan kompetitif perusahaan yang didasarkan pada tanggapan dan penghargaan dari keinginan konsumen mereka di Malaysia. ${ }^{[23]}$ Dalam skala Asia, implementasi CSR ditunjukan dapat dipengaruhi oleh manajer senior dan sesuai dengan budaya yang mereka pegang, hal ini memainkan peran penting dalam mengarahkan investasi CSR perusahaan-perusahaan Asia. Selain itu, konteksnya (negara asal dan negara perusahaanoperasi) juga membedakan nilai budaya dan investasi CSR di ketiga negara ini (Taiwan, Malaysia and Singapore). ${ }^{[2]}$

Berbeda dengan penelitian di jurnal lain, penelitian ini menyebutkan bahwa etika perusahan merupakan fakto rutama yang memotivasi organisasi untuk terlibat dalam kegiatan CSR. Jurnal ini mengungkapkan walaupun ada beberapa faktor yang dapat mempengaruhi implementasi CSR di organisasi seperti kebijakan pemerintah, globalisasi, pelanggan dan investor, kelompok sosial dan lingkungan, maju dalam teknologi komunikasi, namun dalam penelitian ini, etika perusahaan merupakan faktor utama yang dapat memotivasi organisasi untuk terlibat dalam kegiatan CSR. Ini menunjukan bahwa organisasi sangat dipengaruhi oleh etika bisnis dan adanya dorongan kesadaran kewajiban moral perusahaan untuk memberikan kembali sesuatu yang bermanfaat kepada lingkungan di sekitarnya. Walaupun pemerintah dapat memberlakukan peraturan untuk memaksa perusahaan agar terlibat dalam menerapkan CSR, tetapi pada akhirnya, hanya etika organisasi itu sendirilah yang akan mempengaruhinya dalam membuat keputusan independen untuk memilih secara aktif terlibat di dalamnya atau tidak karena mereka sendiri yang akan menganalisis dan mengenali kebutuhan penting dari kegiatan CSR. ${ }^{[25]}$ Selain etika perusahaan, penelitan lain mengungkapkan bahwa kurangnya pemahaman tentang CSR dan pendekatan implementasi CSR yang sistematis akan mempengaruhi penerapan CSR di perusahaan tersebut terlepas dari pengembangan visi dan tujuan. ${ }^{[26]}$

Berdasarkan analisis reabilitas semua faktor praktik CSR diterima secara valid untuk implementasi CSR dalam penelitian di industry otomotif Malaysia. ${ }^{[27]}$ Penelitian lain yang membeda kan dimana tempat pengimplementasian faktor CSR. Faktor - faktor ini meliputi ukuran perusahaan, jenis sektor yang berada dalam sektor indutru, profitabilitas, serta tata kelola perusahaan. Faktor - faktor tersebut mendorong adanya pelaporan CSR di negara maju dan negara berkembang. Negara maju lebih memperhatikan para pemangku kepentingan seperti para pemegang saham, investor, dan media. Hal tersebut dianggap sangat penting dalam mengungkapkan informasi CSR. Sedangkan di negara berkembang pelaporan CSR dipengaruhi oleh adanya kekuatan dari pihak eksternal atau pemegang saham mayoritas. ${ }^{[28]}$ Beberapa berpendapat bahwa negara berkembang yang menerapkan CSED yang dijelaskan dengan teori legitimasi dan teori pemangku kepentingan. Dalam penelitian ini adanya argument bahwa perusahaan dapat dihadapkan pada saat yang sama dengan memberikan tekanan normative, paksaan, dan tekanan mimesis pada perusahaan dalam konteks organisasi. Semakin tinggi tekanan maka semakin cepat praktik perusahaan untuk terlihat serupa dengan perusahaan lain yang beroperasi di lingkungan organisasi. ${ }^{[29]}$

CSR memiliki efek yang rendah dikarenakan kurangnya pengetahuan konsumen tentang CSR, dari hasil analisis ini konsumen yang tahu tentang CSR yang benar - benar dapat mengimplementasikan kegiatan CSR ini. ${ }^{[30]}$ Pendekatan CSR dapat mengidentifikasi organisasi, sehingga dapat menghasilkan internal organisasi yang dapat melayani komunitas di dalamnya tanpa adanya beban, ${ }^{[31]}$ CSR dapat memberikan pedoman dalam industri konstruksi. Hal ini dapat diterapkan dalam lingkungan perusahaan yang dapat membantu para kontraktor. ${ }^{[32]}$ sedangkan dalam industri 
manufaktur lain CSR dapat memberikan wawasan tentang kebijakan lingkungan dalam daya saing perusahaan. Pendekatan alternative dengan melakukan penggabungan informasi dari banyak informan dan mempertimbangkan laju perubahan dari beberapa industry yang lain ${ }^{[9]}$ Dalam lingkungan bisnis yang lain CSR dipandang lebih positif dalam memenuhi etika bisnis yang dibuat untuk memperkuat kepercayaan masyarakat pada perusahaan. ${ }^{[33]}$ Jurnal lain yang menyebutkan bahwa faktor implementasi dari CSR di suatu entitas adalah faktor dari invesment yang tertarik untuk menginvestasikan dananya untuk entitas yang mengimplementasikan CSR dengan baik di bidang sosial termasuk bidang (1) keterlibatan dalam komunikasi (2) keberagaman (3) hubungan karyawan (4) lingkungan (5) penambahan kompensasi eksekutif (6) kontrak militer (7) tenaga nuklir (8) produk keamanan dan (9) program berkualitas. ${ }^{[1]}$ Pengimplementasian CSR yang salah satu nya memperhatikan kesehatan dapat mempengaruhi kinerja karyawan karena ideal nya menurut OSRAH (Organitation Social Responsibility and Accountability for Health) yang mendapatkan pengimplementasian CSR adalah karyawan dan keluarganya, klien dan kontraktor, komunitas lokal, masyarakat dan lingkungan. Selain meningkatkan kinerja karyawan dapat pula dukungan dari masyarakat dan lingkungan untuk meningkatkan perusahaan tersebut ${ }^{[34]}$ Pengimplementasian CSR yang secara bertahap dan terus menerus akan terus mempertahankan invesor yang berinvestasi dan tidak menutup kemungkinan investor semakin banyak yang tertarik sehingga dana yang dibuttuhkan perusahaan akan cukup untuk kepentingan pembangan perusahaan tersebut. ${ }^{[35]}$ Pengimplementasian dari CSR diharapkan dapat terciptanya inovasi dari program sosial,lingkungan , dorangan mental, atau keberanian dalam menciptkan kinerja baru, ruang baru, layanan proses dan produk baru yang di ciptakan oleh karywan itu sendiri tanpa adanya keterpaksaan dari pihak pemegang ${ }^{[2]}$ sifat yang dinamis dan responsif pemangku kepentingan, menggambarkanCSR sebagai proses perubahan organisasi yang melibatkan tidak hanya "mengidentifikasidan mengelola harapan pemangku kepentingan "tetapi juga" belajar dari waktu ke waktu dankemampuan untuk memahami konteks spesifik dan diharapkan pertemuan pemangku kepentingan juga mempengaruhi pengimplementasian CSR dari pihak eksternal selain dari pihak internal yaitu manajemen secara sukarela untuk melakukan kegiatan CSR tersebut. ${ }^{[36]}$

Pada perusahaan yang memproduksi olahan makanan, biasanya perusahaan tersebut harus memiliki berbagai sertifikasi. Dengan mengimplementasikan CSR dapat mempermudah perusahaan tersebut mendapatakan sertifikat dengan pengimlementasian CSR secara baik dan mengurangi biaya yang konstan dengan pertimbangan pendapatan yang masuk ${ }^{[37]}$ Tidak dapat di pungkiri setiap perusahaan, organisasi, dan lain sebagainya memiliki karyawan ataupun highlevel yang melakukan budaya korupsi dan itu di anggap lumrah. Salah satu alasan pengimplementasian CSR ini pun untuk mengurangi tingkat korupsi di dalam perusahaan ataupun organisasi tersebut karena karyawan di tuntut untuk bersikap adil dan jujur dalam CSR internal perusahaann sehingga dapat meminamalisir praktik korupsi. ${ }^{[38]}$ Praktik CSR yang memperhatikan komponen produksi yang di larang/ ilegal hingga loyalitas pembelipun meningkat untuk membeli produk. ${ }^{[39]} 88 \%$ konsumen memiliki kesadaran tentang keterlibatan CSR yang di implementasikan oleh perusahaan yang memproduksi produk yang di butuhkan masyarakat luas sehingga praktis CSR ini akan meningkatkan tingkat penjualan. ${ }^{[40]}$

\section{KESIMPULAN DAN SARAN}

Penelitian ini menunjukkan bahwa terdapat faktor yang mempengaruhi implementasi CSR di perusahan misalnya usia perusahaan, jenis industry, ukuran perusahaan, permintaan karyawan, kebijakan pemerintah, budaya organisasi, dan permintaan pelanggan. Dalam temuan kualitatif menunjukkan bahwa penelitian ini dilihat dari usia perusahaan yang lebih sensitif terhadap lingkungan. Sedangkan menurut temuan kuantitatif melaui pengujian statistic menyebutkan bahwa banyaknya perusahaan yang kepemilikannya sebagian besar dikuasai oleh orang asing lebih sering melakukan kegiatan CSR. Keterlibatan CSR dapat menciptakan itikad baik bagi organisasi perusahaan dan seiring waktu akan mempengaruhi peningkatan kepedulian terhadap 
adanya tanggung jawab sosial perusahaan. Dari salah satu jurnal juga menyebutkan bahwa adanya perbedaan antara budaya organisasi di beberapa negara seperti negara berkembang dan negara maju. Dalam studi ini, kontribusi penelitian ini adalah untuk menunjukkan karakteristik perusahaan yang memainkan peran penting dalam praktik penerapan CSR perusahaan. Pertama penelitian ini menyediakan analisis faktor faktor yang dapat mempengaruhi penerapan CSR di perusahaan sehingga dapat membantu investor dalam memilih perusahaan yang menerapkan CSR paling banyak, karena semakin tinggi penerapan CSR diperusahaan tersebut, maka citra perusahaan tersebut baik di masyarakat. Kedua, perusahaan perusahaan diluaran sana dapat menggunakan temuan penelitian untuk membantu meningkatkan penerapan CSR mereka melalui berbagai faktor yang ada dalam perusahaan mereka. Seperti kebanyakan penelitian sejenisnya, hasil penelitian akan memiliki beberapa keterbatasan. Salah satu batasan potensial dari penelitian ini adalah metode yang kami pakai hanya metode literarute review saja. Kami mengakui bahwa penelitian ini tidak langsung dilakukan terjun ke lapangan, hanya melalui analisis jurnal jurnal saja. Keterbatasan lain dari penelitian ini adalah bahwa jurnal yang digunakan hanya terbatas sebanyak 30 buah. Karena penelitian ini terbatas, oleh karena itu, hasil penelitian ini harus ditafsirkan dengan hati-hati. Penelitian lebih lanjut dapat dilakukan untuk menguji faktor-faktor lain yang mungkin mempengaruhi pengungkapan dan penerapan CSR

Penulisan simpulan dan saran ditulis dalam bentuk paragraf mengalir. Simpulanmemaparkan kesimpulan akhir yang dituliskan dengan singkat dan jelas, menunjukkan kejelasan sumbangan temuan, pencetusan teori baru dan kemungkinan pengembangan penelitian yang bisa dilakukan kedepannya. Selain itu simpulan berisi implikasi penelitian baik secara teoritis maupun praktis. Simpulan hendaknya merupakan jawaban atas pertanyaan penelitian, dan diungkapkan bukan dalam kalimat statistik.

\section{DAFTAR PUSTAKA}

${ }^{1}$ Mcwilliams A. Strategic Management: A Stakeholder Approach.; 2014.

2. Cegarra-navarro JG, Reverte C, Eduardo G. The
Influence Of Corporate Social Responsibility Practices On Organizational Performance: Evidence From Eco-Responsible Spanish Firms. 2016;112:2870-2884.

doi:10.1016/j.jclepro.2015.09.128

${ }^{3}$ Park S, Levy SE, Park S, Levy SE. Corporate social responsibility: perspectives of hotel frontline employees. 2015. doi:10.1108/IJCHM01-2013-0034

4. Boesso G, Favotto F, Michelon G. Stakeholder Prioritization, Strategic Corporate Social Responsibility and Company Performance: Further Evidence. 2014. doi:10.1002/csr.1356

${ }^{5}$ Rayton BA, Brammer SJ, Millington AI. Corporate Social Performance and the Psychological Contract. 2014. doi:10.1177/1059601114561476

${ }^{6}$ Hydro N. Corporate social responsibility in the oil and gas sector. 2010;2(3). doi:10.1093/jwelb/jwp012

${ }^{7}$ Guthrie J, Parker LD, Guthrie J, Parker LD. Legitimacy Theory Corporate Social Reporting: A Rebuttal of Legitimacy Theory *. 2012;(December 2014):37-41. doi:10.1080/00014788.1989.9728863

8. Wilmshurst TD, Frost GR. Corporate environmental reporting A test of legitimacy theory. 2000;13(1):10-26.

9. Bhardwaj BR. Benchmarking: An International Journal Role of green policy on sustainable supply chain management: a model for implementing corporate social responsibility (CSR). 2016.

${ }^{10 .}$ Ye M, Lu W, Flanagan R. Corporate social responsibility " glocalisation" : Evidence from the international construction business. 2019;(June):115. doi:10.1002/csr.1831

${ }^{11 .}$ Il B, Ghauri PN. Determinants influencing CSR practices in small and medium sized MNE subsidiaries : A stakeholder perspective $\S$. J World Bus. 2014. doi:10.1016/j.jwb.2014.04.007

${ }^{12}$. Chung K, Yu J, Choi M, Shin J. The Effects of CSR on Customer Satisfaction and Loyalty in China : The Moderating Role of Corporate Image. 2015;3(5). doi:10.7763/JOEBM.2015.V3.243

${ }^{13 .}$ Bayoud NS, Kavanagh M, Slaughter G. Factors Influencing Levels of Corporate Social 
Responsibility Disclosure by Libyan Firms: A Mixed Study. 2012;4(4):13-29. doi:10.5539/ijef.v4n4p13

14. Purificación M, Villardón G, Esteban VA, María I, Sánchez G, David F. An Extension Of The Industrial Corporate Social Responsibility Practices Index : New Information For Stakeholder Engagement Under A Multivariate Approach. 2019;(May 2018):127-140. doi:10.1002/csr.1665

15. John-okeke R. Corporate Social Responsibility : Challenges Of Implementing Mtn Digital Libraries In Nigerian. 2016;(August).

16. Flammer C, Flammer C. Does Corporate Social Responsibility Lead to Superior Financial Performance? A Regression Discontinuity Approach Does Corporate Social Responsibility Lead to Superior Financial Performance? A Regression Discontinuity Approach. 2015;(July).

${ }^{17}$ Kučerová R, Skýpalová R, Blašková V. Factors Influencing The Implementation Of The Csr Concept In The Czech Republic. 2015;63(6):19791985.

18. S.A A, F.F O, K.O A. An Evaluation of factors Influencing Corporate Social Responsibility in Nigerian Manufacturing Companies. 2013;2(6):54-63. doi:10.6007/IJAREMS/v2i6/441

19. Perry P. Exploring The Influence Of National Cultural Context On CSR Implementation. 2012. doi:10.1108/13612021211222806

${ }^{20 .}$ Kalyar MN, Ra N, Kalyar AN. Factors Affecting Corporate Social Responsibility: An Empirical Study. 2013;505(July 2012):495-505. doi:10.1002/sres

${ }^{21 .}$ Nga DPTH. Factors Affecting Corporate Social Responsibility (Csr): A Case Of Commercial Banks In Ho Chi Minh City. 2017;5(4):43-53.

${ }^{22}$ Hussainey K, Elsayed M, Razik MA. Factors Affecting Corporate Social Responsibility Disclosure In Egypt. 2011;8(4):432-443.

23. P MRAM, Yong P, Keen C, Mah J, Shawn W, Ping LC. Factor Affecting Corporate Social Responsibility for Socially Responsible Companies in Malaysia. 2013;3(2):103-107. doi:10.5923/j.economics.20130302.07

24. Ling Y-H. Cultural and contextual influences on corporate social responsibility A comparative study in three Asian countries. 2019. doi:10.1108/CCSM-02-2018-0024

25. Anyangoooko G. The Environmental Factors That Influence Implementation Of Corporate Social Responsibility ( CSR ) In an Organization. 2014;19(12):95-102.

26.Vilke R. CSR Development Problems In Lithuania: Evaluation Of Promoting And Hindering Factors. 2011;7(4):604-621. doi:10.1108/17471111111175164

27. Fuzi NM, Habidin NF, Hibadullah SN, et al. Critical Success Factors Of Corporate Social Responsibility Practices For The Malaysian Automotive Industry. 2015;(June). doi:10.1504/IJCA.2015.069950

28. Ali W, Frynas JG, Mahmood Z. Determinants of Corporate Social Responsibility (CSR) Disclosure in Developed and Developing Countries: A Literature Review. 2017. doi:10.1002/csr.1410

29. Ali W, Rizwan M. Factors Influencing Corporate Social And Environmental Disclosure ( Csed ) Practices In The Developing Countries: An Institutional Theoretical Institutional Theoretical Perspective. 2013;(August 2015).

30. Boccia F, Sarnacchiaro P. The Impact of Corporate Social Responsibility on Consumer Preference: A Structural Equation Analysis. 2017. doi:10.1002/csr.1446

31. Pradhan V, Sharma RK, Krishnamurthy S. Analyses of Factors Affecting Employee Perception on Orgnizational Corporate Social Responsibility. 2016;(March 2017).

32.Jiang W, Wong JKW. Key activity areas of corporate social responsibility ( CSR ) in the construction industry: a study of China. J Clean Prod. 2016;113:850-860. doi:10.1016/j.jclepro.2015.10.093

33. Narwal DM, Sharma DT. Perceptions of Corporate Social Responsibility in India: an Empirical Study Perceptions of Corporate Social Responsibility in India: An Empirical Study. 2016;(January).

${ }^{34}$.Mohammadi NK, Taheri F, Motallebi M, et al. Original Article Development of a national conceptual framework and measuring tool for 
Organisational Social Responsibility and Accountability for Health ( OSRAH ). 2019;0(0):19. doi:10.1177/1757975918789346

35. Ayub SE, Onditi A, Michael N. Role of Corporate Social Responsibility in the Relationship between Strategy Analysis and Organizational Performance of Sugar Companies in Western Kenya. 2017;5(April):335-342.

36. Athanasopoulou A, Selsky JW. The Social Context of Corporate Social Responsibility: Enriching Research With Multiple Perspectives and Multiple Levels. 2015. doi:10.1177/0007650312449260

37. Del T, Stranieri S, Caracciolo F, et al. Corporate Social Responsibility certi fi cations in fl uence consumer preferences and seafood market price. 2018;178:526-533. doi:10.1016/j.jclepro.2017.12.276

38. Deus RM, Michel B, Pais R. Organisational Challenges to Corporate Social Responsibility. 2019:207-219.

39. Al-zyoud I. Impact of Corporate Social Responsibility Implementation in Jordanian Public Shareholding Companies on Sustainable Development. 2017;13(2):94-106. doi:10.5539/ass.v13n2p94

40. Akterujjaman SM. Business case of corporate social responsibility: A case study on Columbia Garments Limited in Bangladesh. 2019;(February):265-271. doi:10.1002/bsd2.67 